\author{
Sebastian KUBALA, MSc \\ Department of Organizations Development, Cracow University of Economics \\ e-mail:kubalas@uek.krakow.pl \\ ORCID: 0000-0003-4021-9173 \\ Chrystian Bernard FIRLEJ, MSc \\ Faculty of Agriculture and Economics, University of Agriculture in Krakow \\ e-mail: c.firlej@urk.edu.pl \\ ORCID: 0000-0001-7724-5717
}

DOI: $10.15290 /$ oes.2020.03.101.11

\title{
IMPACT OF NET WORKING CAPITAL MANAGEMENT STRATEGY ON FINANCIAL RESULTS ON THE EXAMPLE OF WIG-FOOD COMPANIES ${ }^{1}$
}

\begin{abstract}
Summary
Purpose - The main purpose of the work is to analyse the relationship between the net working capital management strategy and selected financial results of enterprises belonging to the WIG-food index.

Research method - As part of the assessment, the financial data of 12 companies belonging to the WIG-food index for the period 2008-2018 were analysed. The dependent variables were the following measures: net profit/loss (NPL), current liquidity ratio (CLR), inventory turnover ratio (ITR), general debt ratio (GDR), return on sales (ROS). To achieve the objective of the research a one-way ANOVA variance was used.

Results - The research results indicate that the net working capital management strategy adopted by the companies belonging to the WIG-Food index significantly affects the achieved financial results.

Originality/value - The conducted research showed that the most common differences in shaping individual financial results occur between the use of aggressive $(\mathrm{A})$ and conservative $(\mathrm{C})$ strategy, aggressive (A) and moderately conservative (MC) strategy, conservative (C) and moderately aggressive (MA) strategy, as well as moderately aggressive (MA) and moderately conservative (MC) strategy.
\end{abstract}

Keywords: financial ratios, food industry, analysis of variance

JEL Classification: G32, L66

\section{Introduction}

One of the financial elements that has a significant impact on the proper functioning of the enterprise is working capital. The main task of working capital is to reduce the risk that results from the immobilization of a part of current assets or re-

1 Article received on 10 March 2020, accepted on 02 August 2020. 
sults from losses that are associated with these assets. As indicated by Gołębiowski and Tłaczała [2009, p. 193]: "Proper management of working capital will lead to an increase in operational efficiency, which will be the result of optimizing the size and structure of current assets, shaping the most favourable structure of financing sources, and thus the increase of profitability and competitiveness of the company."

Studying the relationship between the working capital management strategy and selected financial variables is a frequently discussed topic. It has been dealt with by, among others, Ćwięk and Jaki [2015, pp. 257-267], who studied the impact of net working capital on the value of an enterprise. In turn, Wasilewski and Zabolotny [2009, pp. 5-20] checked the relationships between different net working capital management strategies and the financial situation of listed companies in the food industry. O the other hand, Bieniasz and Gołas [2009, p. 226] determined the impact of the adopted strategy of net working capital management on achieved profits in individual farms. And the goal of Wasilewski [2006, pp. 217-221] was to identify and interpret the nature of partial financial liquidity strategies in terms of incomerisk in agricultural enterprises depending on the level of return on assets.

However, the works of the indicated authors lack an analysis of the existing relationships between the net working capital management strategy and a wide spectrum of financial measures. At the same time, no research was undertaken that was based on the use of tools for analysing variance. Therefore, the main purpose of the work was to analyse the relationship between the net working capital management strategy and selected financial results of enterprises belonging to the WIG-food index. The adopted research hypothesis is: the management strategy of net working capital of enterprises belonging to the WIG-food index has a significant impact on the financial results.

\section{The role of net working capital in the functioning of an enterprise}

In practice, two types of working capital are distinguished: gross working capital and net working capital. The first is understood as the total value of the company's current assets shown in the assets of its balance sheet. The part of the fixed capital that covers current assets is called net working capital [Brigham, Houston, 2012, p. 621]. It can be calculated according to two formulas:

$$
\text { Net working capital }=\text { fixed } \text { capital }- \text { current assets }
$$

Or

Net working capital $=$ current assets - current liabilities

In practice, net working capital may take different levels - positive, zero or negative. A positive differential between fixed capital and fixed assets means that a part of the company's current assets is financed by the long-term capital and that they remain at its constant disposal. It should be remembered, however, that interest should be paid on foreign capital, which is beneficial when the average rate of return 
on capital of a company exceeds the interest rate in the economy [Sierpińska, Wędzki, 1997, pp. 76-77].

Zero working capital is extremely rare (in a short period of time it can take values close to zero). This situation occurs when all fixed assets are financed with the fixed capital and current assets are financed with the short-term capital.

The third level of working capital - negative working capital - occurs when a given company has no net working capital, fixed assets reach a higher level than the fixed capital and a part of long-term assets is financed by the short-term liabilities [Sierpińska, Jachna, 2004, p. 80].

The calculation of working capital was used in the study of capital and property structure. It is based on the comparison of net working capital and selected elements of assets. One of the most important indicators is the share of net working capital in financing total assets, which is calculated according to the formula [Gabrusewicz, 2014, p. 168]:

Share of net working capital in financing total assets
$=$ net working capital / total assets $\mathrm{x} 100$

This indicator presents the percentage of total assets constituting measures ensuring financial balance of the enterprise. It is often used to determine the adopted financing strategy of an enterprise. Practical strategies for shaping the size and structure of working capital can be divided into:

- conservative,

- moderate,

- aggressive.

The conservative strategy is aimed at maintaining relatively high levels of cash, inventory, materials and raw materials intended for production, as well as the level of finished products [Czekaj, Dresler, 1996, p. 152].

Pursuant to the assumption of using a moderate strategy, an enterprise finances fixed assets with fixed capital, although in the case of this strategy the share of current liabilities in financing current assets is higher than in the case of conservative strategy [Ostaszewski, 2015, p. 194]. In this case, net working capital is reduced, which may result in financial problems that relate to the repayment of current liabilities. The advantage of a moderate strategy is the reduction in the costs of using capital, although the level of financial risk increases in this case.

The aggressive strategy aims to minimize the level of fixed assets and to apply a restrictive credit policy to customers. With this strategy, the level of net working capital approaches zero or is negative. 


\section{Methods and organization of research}

Qualitative and quantitative methods were used in the conducted research. The qualitative methods used literature studies including books and scientific articles. In the scope of quantitative methods, statistical methods were used, which was necessary to achieve the adopted purpose of the work.

To accomplish the research objective, a one-way ANOVA variance, understood as a method that determines the existence of differences between means in several populations, was used [Aczel, Sounderpandian, 2018, p. 509]. It is, therefore, used to study measurable observations that depend on one or several factors, while explaining whether they can be the reason for differences between group means. ANOVA examines the hypothesis of equality of means, i.e.:

$$
\begin{gathered}
\mathrm{H}_{0}: \mathrm{m}_{1}=\mathrm{m}_{2}=\ldots=\mathrm{m}_{\mathrm{k}} \\
\mathrm{H}_{1}: \mathrm{m}_{\mathrm{i}} \neq \mathrm{m}_{\mathrm{j}} \text { for some } \mathrm{i} \neq \mathrm{j}
\end{gathered}
$$

The test statistic provides an answer to the question of how much of the total variation results from the action of the compound and how much from the randomness of the phenomenon. The statistics have the distribution $\mathrm{F}$ with $k-1$ and $n-k$ degrees of freedom, where $k$ is the number of degrees of the factor under consideration and $n$ is the sample size. In order to verify the hypothesis on equality of means, the analysis of variance table should be completed (table 1).

TABLE 1

Variance analysis table (single classification)

\begin{tabular}{|l|c|c|c|c|}
\hline $\begin{array}{l}\text { Source of } \\
\text { variation }\end{array}$ & $\begin{array}{c}\text { Degrees } \\
\text { of free- } \\
\text { dom }\end{array}$ & Sum of squares & Mean square & Test statistics \\
\hline $\begin{array}{l}\text { between } \\
\text { groups } \\
\text { (objects) }\end{array}$ & $\mathrm{k}-1$ & $\mathrm{SSA}=\sum_{\mathrm{i}=1}^{\mathrm{k}}\left(\overline{\mathrm{X}}_{\mathrm{i}}-\overline{\mathrm{X}}\right)^{2} \mathrm{n}_{\mathrm{i}}$ & $\mathrm{MSA}=\frac{\mathrm{SSA}}{\mathrm{k}-1}$ & $\mathrm{~F}=\frac{\mathrm{MSA}}{\mathrm{MSE}}$ \\
\hline $\begin{array}{l}\text { within } \\
\text { groups } \\
\text { (error) }\end{array}$ & $\mathrm{n}-\mathrm{k}$ & $\mathrm{SSE}=\sum_{\mathrm{i}=1}^{\mathrm{k}} \sum_{\mathrm{j}=1}^{\mathrm{n}_{\mathrm{i}}}\left(\mathrm{X}_{\mathrm{ij}}-\overline{\mathrm{X}}_{\mathrm{i}}\right)^{2}$ & $\mathrm{MSE}=\frac{\mathrm{SSE}}{\mathrm{n}-\mathrm{k}}$ & \\
\hline total & $\mathrm{n}-1$ & $\mathrm{SSA}=\mathrm{SSA}+\mathrm{SSE}$ & $\mathrm{MST}=\frac{\mathrm{SST}}{\mathrm{n}-1}$ & \\
\hline
\end{tabular}

Source: own study based on: [Górecki, 2011, p. 255].

The ANOVA method often makes use of the fact that variances can be grouped into parts, in this case the inter-group and intra-group variance. The variability of SSE within a given group is defined as the error variance. This means that it cannot 
be easily explained or calculated. It is possible to explain the variability of SSA effects that is caused by differences in means between groups.

When conducting the ANOVA test, it is necessary to take into account a number of assumptions [Rabiej, 2012, p. 167]:

- independence of random variables in the considered populations (groups),

- measurability of analysed variables,

- normality of the distribution of variables in each population (group),

- homogeneity of variance in all populations (groups).

The first stage of the research relates to the selection of enterprises and examining the size of individual financial indicators. The survey covered 12 companies listed on the Warsaw Stock Exchange (WSE), which, according to the classification used by the WSE, are included in the food industry:

1. Agroton Public Limited

2. Ambra S.A.

3. Astarta Holding N.V.

4. Industrial Milk Comapy S.A.

5. Indykpol S.A.

6. Kernel Holding S.A.

7. Zakłady Tłuszczowe Kruszwica S.A.

8. Makarony Polskie S.A.

9. Pamapol S.A.

10. Przedsiębiorstwo Przemysłu Spożywczego Pepees S.A.

11. Seko S.A.

12. Wawel S.A.

In order to ensure the homogeneity of the surveyed enterprises, currently listed companies for the years 2008-2018 are subject to examination. The research focuses on determining five financial measures for selected enterprises, calculated on the basis of data from annual financial statements:

- net profit (loss) (NPL),

- current liquidity ratio $(\mathrm{CLR})=$ current assets / current liabilities,

- inventory turnover ratio (ITR) = net revenues from sales of products, goods and materials / average inventory,

- $\quad$ general debt ratio $(\mathrm{GDR})=$ total liabilities / total assets,

- $\quad$ return on sales $(\mathrm{ROS})=$ net profit (loss) / net revenues from sales of products goods and materials $\times 100$.

The management strategy of net working capital of enterprises was determined on the basis of the indicator of the share of working capital in the total assets. The division of companies was conducted using the quartile method:

1. Aggressive strategies (A) included companies with index sizes smaller than the first - bottom quartile ( $25 \%$ of the surveyed group).

2. Conservative strategies (C) included companies with index sizes greater than or equal to the third - upper quartile ( $25 \%$ of the surveyed group).

3. Moderate strategies (M) (50\% of the surveyed group) included enterprises with index sizes greater than or equal to the first quartile and smaller than 
the third quartile. Moderately aggressive strategies (MA) for which the index was greater than or equal to the first quartile but less than the median as well as moderately conservative strategies (MC) where the index was greater than or equal to the median and less than the third quartile will be distinguished.

The next stage of the research was the use of ANOVA. The assumption about the normality of the distribution of variables in each population (group) was carried out using the Anderson-Darling test, which makes two opposing statistical hypotheses [Anderson, Darling, 1952, pp. 193-212]:

H0: The distribution of data is consistent with the normal distribution,

H1: The distribution of data is not consistent with the normal distribution.

In order to check whether there are reasons to reject the null hypothesis, $\mathrm{p}$ values are used. In a situation in which the $\mathrm{p}$ value is lower than the assumed level of significance of the 0.05 test, there are no grounds to reject the null hypothesis about the normality of the distribution of the analysed feature.

The study of homogeneity of variance in all populations (groups) was carried out using the Bartlett test. It compares the weighted arithmetic mean of variance with the weighted geometric mean of variance [Stanisz, 2007, p. 341]. The indicated text is based on statistics which have an asymptotic distribution $\chi^{2}$.

If any of these assumptions are not met, it is reasonable to use the non-parametric Kruskal-Wallis test. The interpretation of this test is similar to that of parametric one-way ANOVA, with the difference that this test denotes the equality of average ranks, not average values.

\subsection{Working capital management strategy and achieved financial results}

The following hypotheses were created to determine the individual relationships between the net working capital management strategy and the financial results of companies belonging to the WIG-food index:

H0(i): the distribution of the achieved value of the i-th financial measure in each of the net working capital management strategies is the same (the adopted strategy of net working capital management does not significantly affect the value of the i-th financial measure),

H1(i): at least two strategies differ from the others in terms of the value of the i-th financial measure (the adopted net working capital management strategy significantly affects the value of the $\mathrm{i}$-th financial measure).

When reviewing the data (table 2), it should be stated that in the case of net profit / loss achieved, the lowest average was obtained by enterprises that used an aggressive strategy (A). Units belonging to this group achieved the lowest financial results among the surveyed business units. The use of moderate conservative (MC) and conservative $(\mathrm{C})$ strategies allowed to achieve similar values of the financial result: 
- PLN 139,579.76 net profit in the case of a moderately conservative (MC) strategy,

- $\quad$ PLN 117,192.03 net profit in the case of a conservative strategy (C).

The lowest average values of the current liquidity ratio were noted in the enterprises that used the aggressive strategy (A). Units belonging to this group reached values close to the limit values. The entities using the moderately aggressive strategy (MA) were characterized by the optimal level of financial liquidity. In the case of business entities using moderately conservative strategies (MC), a slight degree of excess liquidity can be visible. The highest level of financial liquidity is observable in the case of enterprises using conservative strategies (C).

The lowest average values of the inventory turnover ratio were noted in the enterprises that used the moderately aggressive (MA) strategy. Units that used a conservative strategy $(\mathrm{C})$ had a similar value. Other units are characterized by a similar level of the inventory turnover ratio (for enterprises using the aggressive strategy (A), the average value of the inventory turnover ratio is 8.06 , while for enterprises using the moderately conservative strategy (MC) it is 8.96).

In the case of the general debt ratio, the lowest values of the ratio were recorded in the enterprises that used a conservative strategy (C). Enterprises that used a moderately conservative (MC) and moderately aggressive (MA) strategy also achieved results below the optimal value, which means that these units have a high degree of financial independence.

TABLE 2

Basic data of dependent variables in individual groups

\begin{tabular}{|l|c|c|c|c|c|}
\hline Strategy & $\begin{array}{c}\text { Dependent } \\
\text { variable: net } \\
\text { profit/loss }\end{array}$ & $\begin{array}{c}\text { Dependent } \\
\text { variable: } \\
\text { CLR }\end{array}$ & $\begin{array}{c}\text { Dependent } \\
\text { variable: ITR }\end{array}$ & $\begin{array}{c}\text { Dependent } \\
\text { variable: } \\
\text { GDR }\end{array}$ & $\begin{array}{c}\text { Dependent } \\
\text { variable: } \\
\text { ROS }\end{array}$ \\
\hline Average \\
\hline A & 3723.67 & 1.04 & 8.06 & 0.58 & 1.49 \\
\hline C & 117192.03 & 6.41 & 5.82 & 0.32 & 7.35 \\
\hline MA & 10738.36 & 1.45 & 4.80 & 0.47 & 1.51 \\
\hline MC & 139579.76 & 2.03 & 8.96 & 0.39 & 8.98 \\
\hline Kurtosis & \multicolumn{7}{|l|}{} \\
\hline A & 8.47 & 0.92 & -0.78 & -1.25 & 13.97 \\
\hline C & 3.98 & 9.05 & -0.69 & -0.75 & 15.05 \\
\hline MA & 2.97 & 0.44 & 0.6 & 1.71 & 2.66 \\
\hline MC & 2.43 & 4.62 & -1.32 & -0.64 & 1.28 \\
\hline Skewness & 2.20 & -1.01 & 0.54 & -0.11 & 3.02 \\
\hline A & 1.67 & 3.15 & 0.88 & 0.29 & -3.49 \\
\hline C & 0.17 & 0.82 & 1.42 & 0.64 & -1.47 \\
\hline MA & 1.86 & 2.14 & 0.32 & -0.09 & 1.24 \\
\hline MC &
\end{tabular}

Source: authors' own study. 
In the return on sales ratios, the lowest average was obtained by the enterprises that used a moderately aggressive (MA) and aggressive (A) strategy. Other entities are characterized by an increased level of return on sales ratio (for companies using a conservative strategy $(\mathrm{C})$ the average value of return on sales ratio is at the level of 7.35 , while for companies using a moderately conservative strategy (MC) it amounts to 8.98$)$.

For all the examined financial results, looking at the average values it can be assumed that the null hypothesis will be rejected in all cases. On the basis of skewness and kurtosis, it can be concluded that in the case of individual financial results there may be problems with the normality of the distribution. In addition, box-andwhisker plots were created to confirm the initial assumptions (chart 1).

CHART 1

Box-and-whisker plot illustrating the relationship between the strategy of net working capital management and individual financial results
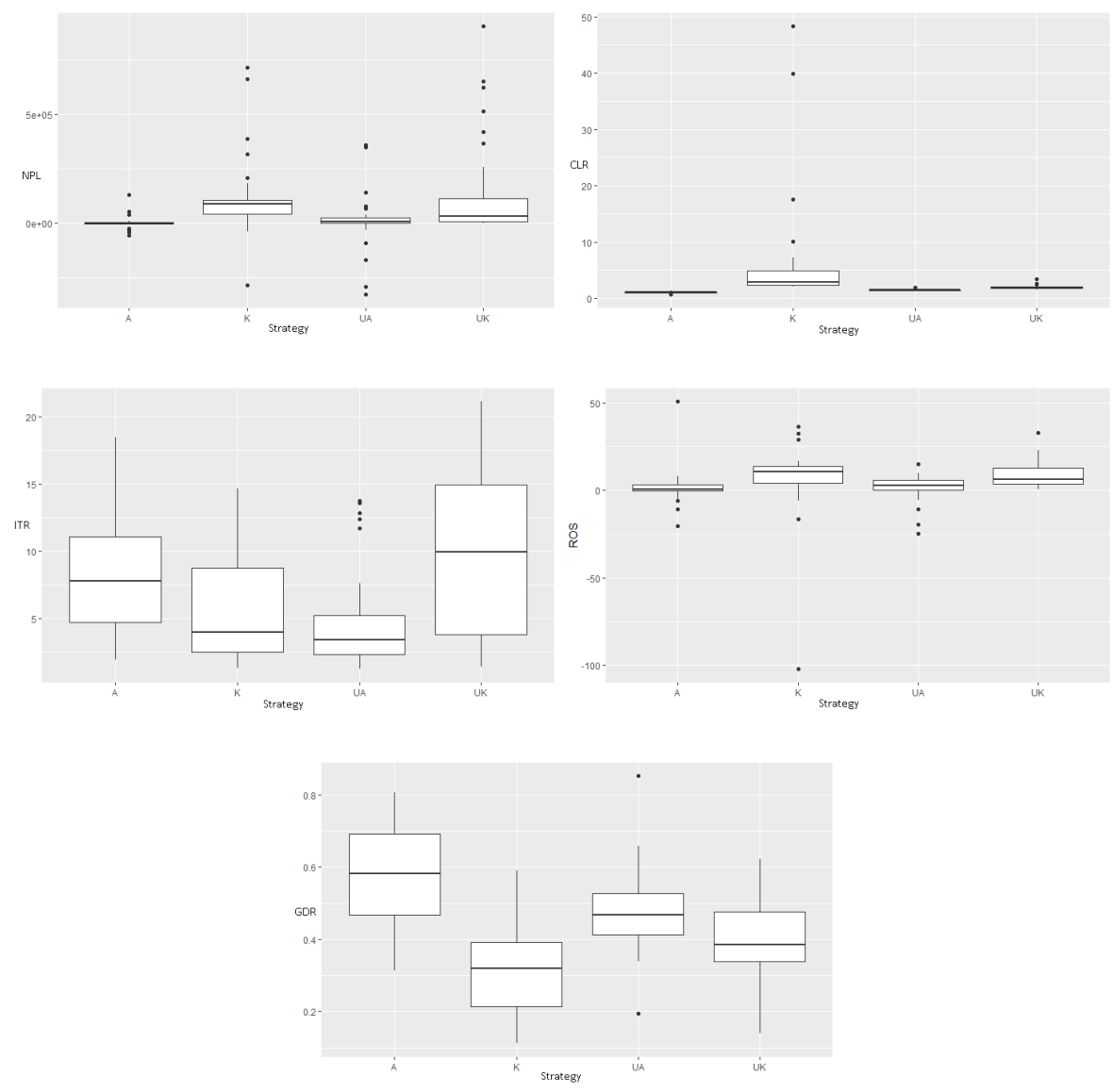

Source: authors' own work. 
In the next stage, the normality of distribution of a dependent variable in each of the analysed groups was verified. The Anderson-Darling test was used to test this assumption. The results of this test are included in table 3 .

The obtained p-values for each group in the case of dependent variables: net profit / loss, current liquidity ratio, inventory turnover ratio and return on sales ratio are below $5 \%$, therefore it should be assumed that normal distribution does not occur in any of the groups.

The obtained p-values for each group in the case of dependent variables: net profit / loss, current liquidity ratio, inventory turnover ratio and return on sales ratio are below $5 \%$, therefore it should be assumed that normal distribution does not occur in any of the groups. In the case of a dependent variable: the general debt ratio, the $\mathrm{p}$-values are above $5 \%$, which indicates that there is a normal distribution in each group.

TABLE 3

\section{Results of the Anderson-Darling test for individual dependent variables}

\begin{tabular}{|c|c|c|c|c|c|c|}
\hline \multirow{2}{*}{ Strategy } & \multicolumn{2}{|c|}{$\begin{array}{c}\text { Dependent variable: } \\
\text { net profit/loss }\end{array}$} & \multicolumn{2}{|c|}{$\begin{array}{l}\text { Dependent variable: cur- } \\
\text { rent liquidity ratio }\end{array}$} & \multicolumn{2}{|c|}{$\begin{array}{l}\text { Dependent variable: in- } \\
\text { ventory turnover ratio }\end{array}$} \\
\hline & $\begin{array}{c}\text { Test } \\
\text { statistics A }\end{array}$ & $\mathrm{p}$-value & $\begin{array}{c}\text { Test } \\
\text { statistics A }\end{array}$ & p-value & $\begin{array}{c}\text { Test } \\
\text { statistics A }\end{array}$ & p-value \\
\hline A & 4.146 & 0.000 & 1.073 & 0.007 & 0,745 & 0,047 \\
\hline $\mathrm{C}$ & 3.615 & 0.000 & 7.268 & 0.000 & 1,969 & 0,000 \\
\hline MA & 3.784 & 0.000 & 0.530 & 0.163 & 3,315 & 0,000 \\
\hline MC & 5.060 & 0.000 & 2.622 & 0.000 & \multirow{2}{*}{$\frac{1,13}{1, y a r i a b l}$} & 0,005 \\
\hline \multirow{2}{*}{ Strategy } & \multicolumn{3}{|c|}{ Dependent variable: general debt ratio } & \multicolumn{2}{|c|}{ Dependent variable: return on sales } & \\
\hline & \multicolumn{2}{|c|}{ Test statistics A } & p-value & \multicolumn{2}{|c|}{ Test statistics A } & p-value \\
\hline A & \multicolumn{2}{|c|}{0.657} & 0.079 & \multicolumn{2}{|c|}{4.121} & 0.000 \\
\hline $\mathrm{C}$ & \multicolumn{2}{|c|}{0.345} & 0.465 & \multicolumn{2}{|c|}{3.754} & 0.000 \\
\hline MA & \multicolumn{2}{|c|}{0.665} & 0.075 & \multicolumn{2}{|c|}{1.406} & 0.001 \\
\hline MC & \multicolumn{2}{|c|}{0.221} & 0.817 & \multicolumn{2}{|c|}{1.176} & 0.004 \\
\hline
\end{tabular}

Source: authors' own work.

Subsequently, the homogeneity of variance was checked using the Bartlett test. The obtained values are presented in table 4 .

The formation of p-value at a level lower than the adopted level of significance indicates that there is no homogeneity of variance. This situation can be encountered in the case of variables: net profit / loss, current liquidity ratio and return on sales ratio. As for the inventory turnover ratio and overall debt ratio variables, the values obtained indicate the occurrence of variance homogeneity. 
TABLE 4

Bartlett test results for individual dependent variables

\begin{tabular}{|c|c|c|c|c|c|}
\hline \multicolumn{2}{|c|}{$\begin{array}{c}\text { Dependent variable: net } \\
\text { profit/loss }\end{array}$} & \multicolumn{2}{c|}{$\begin{array}{c}\text { Dependent variable: current } \\
\text { liquidity ratio }\end{array}$} & \multicolumn{2}{c|}{$\begin{array}{c}\text { Dependent variable: } \\
\text { inventory turnover ratio }\end{array}$} \\
\hline K-squared & p-value & K-squared & p-value & K-squared & p-value \\
\hline 90.261 & 0.000 & 541.670 & 0.000 & 7,723 & 0,0521 \\
\hline Dependent variable: general debt ratio & \multicolumn{2}{c|}{ Dependent variable: return on sales } \\
\hline \multicolumn{2}{|c|}{ K-squared } & p-value & \multicolumn{2}{c|}{ K-squared } & p-value \\
\hline 0.518 & 0.915 & 55.306 & & 0.000 \\
\hline
\end{tabular}

Source: authors' own work.

The conducted Anderson-Darling and Bartlett tests indicate that for each dependent variable the ANOVA test assumptions are not met. Therefore, in further studies, the non-parametric Kruskall-Wallis test was used, whose task was to examine the relationship between the net working capital strategy and individual dependent variables. Table 5 presents the results of the Kruskal-Wallis rank ANOVA test for individual dependent variables.

TABLE 5

\section{Results of the Kruskal-Wallis rank ANOVA test for individual dependent variables}

\begin{tabular}{|c|c|c|c|c|c|}
\hline \multicolumn{2}{|c|}{$\begin{array}{c}\text { Dependent variable: } \\
\text { net profit/loss }\end{array}$} & \multicolumn{2}{c|}{$\begin{array}{c}\text { Dependent variable: current } \\
\text { liquidity ratio }\end{array}$} & \multicolumn{2}{c|}{$\begin{array}{c}\text { Dependent variable: } \\
\text { inventory turnover ratio }\end{array}$} \\
\hline chi-squared & p-value & chi-squared & p-value & chi-squared & p-value \\
\hline 45.878 & 0.000 & 116.430 & 0.000 & 16,632 & 0,001 \\
\hline Dependent variable: general debt ratio & \multicolumn{2}{c|}{ Dependent variable: return on sales } \\
\hline \multicolumn{2}{|c|}{ chi-squared } & p-value & \multicolumn{2}{c|}{ chi-squared } & p-value \\
\hline 53.280 & 0.000 & 38.172 & 0.000 \\
\hline
\end{tabular}

Source: authors' own work.

The obtained results indicate that at the significance level of 0.05 individual null hypotheses should be rejected, which indicates that the distribution of the value of the achieved financial results in each of the working capital management strategies is the same for the alternative hypothesis, according to which at least two strategies differ from the others in terms of values of the financial results. 


\section{Comparative study of the impact of working capital management strategy on achieved financial results}

In order to determine the reasons for significant differentiation of the net working capital strategy and the values of individual variables, the multiple comparison test was used. The obtained results are presented in table 6 .

TABLE 6

\section{Dunn test results with Bonferroni correction}

\begin{tabular}{|c|c|c|c|c|c|c|c|}
\hline \multicolumn{4}{|c|}{ Dependent variable: net profit/loss } & \multicolumn{4}{|c|}{ Dependent variable: current liquidity ratio } \\
\hline Strategy & $\mathbf{A}$ & C & MA & Strategy & $\mathbf{A}$ & C & MA \\
\hline $\mathbf{C}$ & $0.000 * 1$ & - & - & $\mathbf{C}$ & $0.000^{*}$ & - & - \\
\hline MA & 0.204 & $0.000^{*}$ & - & MA & $0.001^{*}$ & $0.000^{*}$ & - \\
\hline MC & $0.000^{*}$ & & & & $0.000^{*}$ & $0.006^{*}$ & $0.001^{*}$ \\
\hline Strategy & A & & & & A & $\mathrm{C}$ & MA \\
\hline $\mathrm{C}$ & 0.044 & - & - & C & 1.000 & $0.004 *$ & $\mathrm{MC}$ \\
\hline MA & $0.003^{*}$ & 1.000 & - & MA & $\begin{array}{l}\text { Dependent } \\
\text { variable: } \\
\text { inventory } \\
\text { turnover } \\
\text { ratio }\end{array}$ & $\begin{array}{l}\text { Dependent } \\
\text { variable: } \\
\text { general } \\
\text { debt ratio }\end{array}$ & - \\
\hline MC & 1.000 & 0.057 & $0.004^{*}$ & MC & $\mathrm{C}$ & MA & Strategy \\
\hline \multicolumn{4}{|c|}{ Dependent variable: return on sales } & \multirow{5}{*}{\multicolumn{4}{|c|}{$1 *$ - statistically significant differences }} \\
\hline Strategy & A & $\mathrm{C}$ & MA & & & & \\
\hline $\mathbf{C}$ & $0.000^{*}$ & - & - & & & & \\
\hline MA & 0.476 & $0.001^{*}$ & - & & & & \\
\hline MC & $0.000^{*}$ & 1.000 & $0.003^{*}$ & & & & \\
\hline
\end{tabular}

Source: authors' own work.

The Dunn test carried out with the Bonferroni correction indicates that in the case of the net profit / loss dependent variable, the lack of significant differences applies only to the enterprises that were characterized by the use of aggressive (A) and moderately aggressive (MA) as well as conservative (C) and moderately conservative (MC) strategies. In other cases, significant differences can be observed.

Considering the dependent variable i.e., the value of the current liquidity ratio, it can be observed that the test results show significant differences in all considered cases.

In turn, in the case of the inventory turnover ratio, a statistically significant difference in the value of this measure is visible between the enterprises that were characterized by the use of aggressive (A) and moderately aggressive (MA) as well as moderately aggressive (MA) and moderately conservative (MC) strategies. In other cases, no significant differences are observable. 
Test results for the general debt ratio show that significant differences only apply to the enterprises that were characterized by the use of aggressive (A) and conservative $(\mathrm{C})$ as well as moderately aggressive (MA) and conservative (C) as well as aggressive (A) and moderately conservative (MC) strategies. In other cases, no significant differences are observable.

In the case of the last dependent variable ie.e., return on sales, the Dunn test with Bonferroni correction indicates that no significant differences occur only in the case of the enterprises that were characterized by the use of aggressive (A) and moderately aggressive (MA) and conservative (C) and moderately conservative strategies (MC). In other cases there are significant differences.

In summary, it should be noted that significant differences in the development of individual financial results are observable at least once in each strategy (table 7).

TABLE 7

Number of significant differences between individual strategies

\begin{tabular}{|l|l|l|c|}
\hline \multicolumn{1}{|c|}{ Strategy } & A & C & MA \\
\hline C & 4 & - & - \\
\hline MA & 2 & 4 & - \\
\hline MC & 4 & 1 & 4 \\
\hline
\end{tabular}

Source: authors' own work.

\section{Conclusions}

In the first three cases, the noticeable differences are the result of significant discrepancies in the activities carried out in line with the adopted strategy. This is particularly noticeable in the case of achieved net profit / loss values, where the enterprises using aggressive (A) or moderately aggressive (MA) strategies achieve significantly lower results than the companies that have conservative $(\mathrm{C})$ or moderately conservative (MC) strategies. Also, in the case of the current liquidity ratio, there is a noticeable hierarchy that depicts the relationship between the achieved values and the strategy used. It should be noted that in the case of the companies belonging to the WIG-food index, the more conservative the strategy of managing net working capital, the higher the level of financial liquidity achieved.

Interesting conclusions can be drawn when considering differences in two types of moderate strategies. Although these strategies are classified as moderate strategies, and therefore use similar policies, significant differences are observable in practically every case (except for the dependent variable: general debt ratio), which confirms the fact that dividing a moderate strategy into a moderately conservative (MC) and moderately aggressive one (MA) is justified. 


\section{References}

Aczel A.D., Sounderpandian J., 2018, Statystyka w zarzadzaniu, WN PWN, Warszawa. Anderson T.W., Darling D.A., 1952, Asymptotic theory of certain "goodness-of-fit" criteria based on stochastic processes, "Annals of Mathematical Statistics", vol. 23(2), pp. 193212.

Bieniasz A., Gołaś Z., 2009, Ptynnosić finansowa gospodarstw rolnych w aspekcie przeptywón pienieżnych i strategii zarzadzania kapitatem obrotonym, Akademia Rolnicza im. Augusta Cieszkowskiego w Poznaniu, Poznań.

Brigham E., Houston J., 2012, Zarzqdzanie finansami, WN PWN, Warszawa.

Czekaj J., Dresler Z., 1996, Podstany zarzadzania finansami firm, WN PWN, Warszawa.

Ćwięk W., Jaki A., 2015, Kapitat obrotony netto a wartość przedsiębiorstwa, „Zeszyty Naukowe Uniwersytetu Szczecińskiego. Finanse, Rynki Finansowe, Ubezpieczenia”, nr 74 , t. 1 , s. $257-267$.

Gabrusewicz W., 2014, Analiza finansowa przedsiebiorstwa. Teoria $i$ zastosowanie, PWE, Warszawa.

Gołębiowski G., Tłaczała A., 2009, Analiza finansowa w teorii i w praktyce, Difin, Warszawa.

Sierpińska M., Jachna T., 2004, Ocena przedsiebiorstwa wedtug standardów śniatowych, WN PWN, Warszawa.

Sierpińska M., Wędzki D., 1997, Zarz̨adzanie plynnościa finansowa w pržedsiębiorstwie, WN PWN, Warszawa.

Ostaszewski J., 2015, Kapitat obrotony netto w przedsiebiorstwie i metody jego pomiaru, [w:] $O$ nony lad finansony w Polsce: rekomendacje dla animatorón ìycia gospodarczego, Ostaszewski J. (red.), SGH, Warszawa.

Rabiej M., 2012, Statystyka ₹programem Statistica, Helion, Gliwice.

Stanisz A., 2007, Praystepny kurs statystyki z zastosowaniem STATISTICA PL na prayketadach z medycyny. Volume 2 - Modele liniowe i nieliniowe, StatSoft Polska, Kraków.

Wasilewski M., 2006, Rentowność przeedsiębiorstw rolnicryych w zależności od strategii zarzqdzania kapitatem obrotowym, „Roczniki Naukowe SERiA”, nr VIII(1), s. 217-221. 